\title{
MANAJEMEN PARENTING DALAM MENINGKATKAN HUBUNGAN SEKOLAH DENGAN ORANGTUA
}

\author{
Emi Lindasari \\ Bambang Budi Wiyono \\ Imron Arifin \\ Email: emilindasari@gmail.com \\ Bank Mandiri KCP Sutan Syahrir \\ Jl. Sutan Syahrir No. 29-31 Malang 65117 Jawa Timur
}

\begin{abstract}
The purpose of this research is to know the implementation of parenting management to improve school public relation (a case study at SDI Surya Buana Malang). This research used the qualitative approach with case study design. The data collected by interview, observation, and documentation. Categorizing the data was taken into account as part of analsis process. This research founds that the implementation of parenting at SDI Surya Buana Malang consists from planning, organizing, implementing, and evaluating.
\end{abstract}

Keywords: parenting management, school and parent's relationship.

\begin{abstract}
Abstrak: Tujuan penelitian ini untuk mengetahui manajemen parenting dalam meningkatkan hubungan antara sekolah dan orangtua di SDI Surya Buana Malang. Penelitian ini menggunakan pendekatan kualitatif dengan jenis penelitian studi kasus. Pengumpulan data melalui wawancara, observasi, dan dokumentasi. Tahap analisis data dengan cara memilahmilah data. Penelitian ini menemukan bahwa manajemen parenting di SDI Surya Buana Malang terdiri dari perencanaan, pengorganisasian, pelaksanaan, dan evaluasi.
\end{abstract}

Kata kunci: manajemen parenting, hubungan sekolah dan orangtua

Pendidikan keorangtuaan (parenting) merupakan sebuah proses memanfaatkan keterampilan mengasuh anak yang dilandasi oleh aturan-aturan yang agung dan mulia (Ilahi, 2013). Orangtua sebagai orang terdekat dengan anak mempunyai peran penting dalam pemberian stimulasi terhadap perkembangan anak, sehingga perlu untuk diperdayakan. Sekolah dan rumah merupakan sarana untuk perkembangan anak. Oleh sebab itu, dalam memaduan pendidikan di sekolah dengan di rumah, harus menjadi perhatian bagi para penyelenggara pendidikan dengan meningkatkan layanan pada anak di lingkungan sekolah. Parenting related meaningfully to mother-rated prosocial behavior and unexplained punishment related positively to self-initiated prosocial behavior (Knafo, dkk., 2011).

Orangtua perlu dapat dilibatkan lebih jauh dalam lingkungan sekolah sebagai mitra kerja atau sebagai pendidik di rumah dengan cara memberikan program pendidikan keorangtuaan (parenting) bagi para orangtua agar mampu menjalankan tugasnya sebagai pendidik. Berkaitan dengan parenting, dalam penelitian ini merupakan salah satu kegiatan yang termasuk dalam program kerja hubungan sekolah dengan masyarakat, yang mana setiap warga masyarakat bercita-cita dan aktif berpartisipasi untuk membina pendidikan (Hasbullah, 2005). Sekolah Dasar Islam (SDI) swasta di Malang yang menerapkan parenting adalah SDI Surya Buana Kota Malang.

Kegiatan parenting di SDI Surya Buana Kota Malang dilaksanakan sejak tahun 2002, sehingga dapat diasumsikan bahwa partisipasi masyarakat yang dilaksanakan selama ini berjalan dengan baik. Manajemen parenting di SDI Surya Buana terdiri dari program parenting berbentuk 
formal seperti seminar dan parenting rutin yang dilaksanakan setiap hari Sabtu. Latar belakang adanya parenting itu sendiri yaitu pentingnya kerjasama antara wali murid dan sekolah, sehingga pendidikan yang diajarkan dapat sejalan antara di sekolah dengan di rumah. Selain itu keberadaan parenting yang merupakan salah satu ciri khas SDI Surya Buana dengan beberapa programnya. Parenting ialah bentuk kegiatan informal yang dilakukan untuk menyelaraskan kegiatan-kegiatan pengasuhan dan pendidikan anak antara di kelompok bermain dan di rumah (Harahap, 2012).

Terdapat dalam teori kognitif sosial yang spekulasi bahwa pengasuhan hangat menumbuhkan dan model empati, yaitu, merasa sama dengan yang lain dan simpati (Eisenberg, dkk., 2005). Program ini ditujukan kepada para orangtua, pengasuh, dan anggota keluarga lain yang berperan secara langsung dalam proses perkembangan anak, dengan demikian kegiatan parenting sangat diperlukan mengingat pentingnya pendidikan. Bentukbentuk kegiatan parenting adalah think-thank; arisan bicara; seminar; praktik ketrampilan; outbound; dan kunjungan lapangan (Harahap, 2012). Think-thank yaitu berupa sumbang saran yang diberikan orangtua kepada sekolah, seperti memberikan pendapat dan diskusi seputar pembelajaran. Misalnya mengenai pembelajaran tematik, setiap anggota dapat menyampaikan gagasan-gagasannya atau memberikan beberapa permasalahan yang sekaligus disertai dengan pembahasannya.

Arisan bicara yaitu dilakukan oleh setiap anggota. Arisan bicara dilakukan dengan cara undian bergilir sebagai pembicara dalam menyampaikan gagasannya yang disesuaikan dengan topik yang telah ditentukan. Seminar dilakukan dengan mengundang narasumber dan sponsor. Praktik ketrampilan misalnya seperti membuat alat permainan edukatif dan memasak makanan bergizi untuk anak. Outbound yaitu kegiatan yang dilakukan di luar ruangan secara bersama-sama oleh semua anggota keluarga. Kegiatan ini disisipkan dengan kegiatan diskusi atau praktik permainan-permainan yang dapat dilakukan oleh anggota keluarga secara bersamasama. Kunjungan lapangan yaitu kegiatan kunjungan yang dilakukan ke tempat-tempat khusus yang bersifat mendidik. Misalnya ke museum, perpustakaan umum, panti asuhan, panti jompo, dan ke kebun atau pertanian.

Pedoman teknis penyelenggaraan pendidikan keorangtuaan (parenting) yang dikeluarkan oleh Direktorat Pendidikan Nonformal dan Informal (2010) menyebutkan bahwa bentuk parenting adalah: (1) kelas orangtua; (2) hari orangtua (parent's day). Kelas orangtua, kegiatan ini merupakan komunikasi bagi orangtua untuk saling berbagi informasi dan pengetahuan. Kegiatan dapat dilakukan dalam bentuk pertemuan orangtua dengan narasumber, baik narasumber dari luar lembaga, pendidik, ataupun sesama orangtua. Jika balita yang orangtuanya dapat menghadiri kelas orangtua, maka menunjukkan peningkatan yang lebih besar dalam perilaku mereka ketika dibandingkan dengan balita yang orangtuanya tidak hadir (Chang dan Sunha, 2009). Hari orangtua (parent's day), kegiatan ini dilakukan dengan melibatkan orangtua atau keluarga dalam proses pembelajaran, yang antara lain: keterlibatan orangtua di dalam kelas, yang dilakukan secara bergilir berdasarkan jadwal yang diatur pendidik; dan kegiatan rekreasi atau kegiatan bersama lainnya.

Tujuan penelitian ini ialah: mendeskripsikan perencanaan parenting dalam meningkatkan hubungan sekolah dengan orangtua; (2) mendeskripsikan pengorganisasian tugas dan tanggung jawab pelaksanaan parenting dalam meningkatkan hubungan sekolah dengan orangtua; (3) mendeskripsikan proses pelaksanaan parenting dalam meningkatkan hubungan sekolah dengan orangtua; dan (4) mendeskripsikan evaluasi parenting dalam meningkatkan hubungan sekolah dengan orangtua di SDI Surya Buana Malang.

\section{METODE}

Rancangan penelitian ialah pendekatan kualitatif dan jenis penelitian studi kasus di SDI Surya Buana Malang. Informan penelitian ialah Direktur Perguruan, Kepala Sekolah, Wakil Kepala Sekolah Kesiswaan, Guru, Orangtua Peserta Didik, dan Peserta Didik. Pengumpulan data melalui wawancara, observasi, dan dokumentasi. Data yang diperoleh kemudian dianalisis dengan cara reduksi data, memilih hal-hal yang pokok, dan memfokuskan pada halhal yang penting. Display data yaitu perakitan informasi yang terorganisasi, memungkinkan 
untuk penarikan kesimpulan dalam bentuk katakata dan bagan. Terakhir yaitu verifikasi data merupakan penarikan simpulan berdasarkan hasil observasi, wawancara, dan dokumentasi dari berbagai sumber atau informasi yang berada di lingkungan sekolah.

Keabsahan data dalam penelitian yang pertama yaitu kredibilitas yakni kesesuaian konsep peneliti dengan konsep yang ada pada sasaran penelitian (Wiyono, 2007). Adapun kredibilitas sumber data melalui triangulasi, baik itu triangulasi sumber data dan triangulasi metodologis. Triangulasi sumber data dengan cara peneliti menggali data tentang pelaksanaan program parenting dari kepala sekolah kemudian dicek keabsahannya kepada yayasan (Direktur Perguruan), wakil kepala sekolah kesiswaan, guru, orangtua peserta didik, dan peserta didik serta dokumen-dokumen yang terkait. Sedangkan triangulasi metodologis yaitu peneliti memilih subjek penelitian secara acak. Keabsahan data selanjutnya yaitu transferabilitas, yakni peneliti dalam membuat laporannya memberikan uraian yang rinci, jelas, sistematis, dan dapat dipercaya (Sugiyono, 2011).

Peneliti dalam hal ini tidak saja menjelaskan situasi tetapi juga mengungkap bagaimana perasaan subjek yang terlibat dalam pelaksanaan. Selanjutnya yaitu dependabilitas yaitu peneliti melakukan pengulangan studi dalam kondisi yang sama dan hasilnya secara esensial sama, seperti peneliti melakukan kegiatan wawancara, dan observasi secara berulang untuk mendapatkan kesimpulan yang sama. Terakhir adalah konfirmabilitas yang mana data empiris diakui kebenarannya oleh partisipan untuk menjamin uji obyektivitas penelitian, seperti peneliti membuat laporan hasil penelitian yang dilakukan secara tertulis yang kemudian diperiksa kebenarannya oleh partisipannya untuk diberikan tanda tangan pada catatan lapangan. Tahap penelitian pada penelitian ini dimulai dari tahap pralapangan mengenai kajian terhadap teori, hasil-hasil penelitian terkait, observasi, serta wawancara langsung terhadap pihak-pihak terkait.

\section{HASIL}

\section{Perencanaan Parenting}

Perencanaan parenting di SDI Surya Buana Malang meliputi bentuk program parenting yang terdiri dari dua bentuk yaitu bentuk formal (seminar) dan rutin (parent's day). Adapun latar belakang diadakannya program seminar yaitu karena kurangnya pertemuan antara sekolah dengan orangtua peserta didik, sehingga dengan adanya program ini dapat meningkatkan komunikasi antara sekolah dengan orangtua peserta didik dan dapat menjalin hubungan yang lebih intensif antara sekolah dengan masyarakat. Perencanaan selanjutnya yaitu mengadakan rapat yang mana dalam rapat tersebut membahas mengenai rumusan tujuan adanya parenting. Kemudian perencanaan berikutnya adalah menentukan kebijakan mengenai adanya program

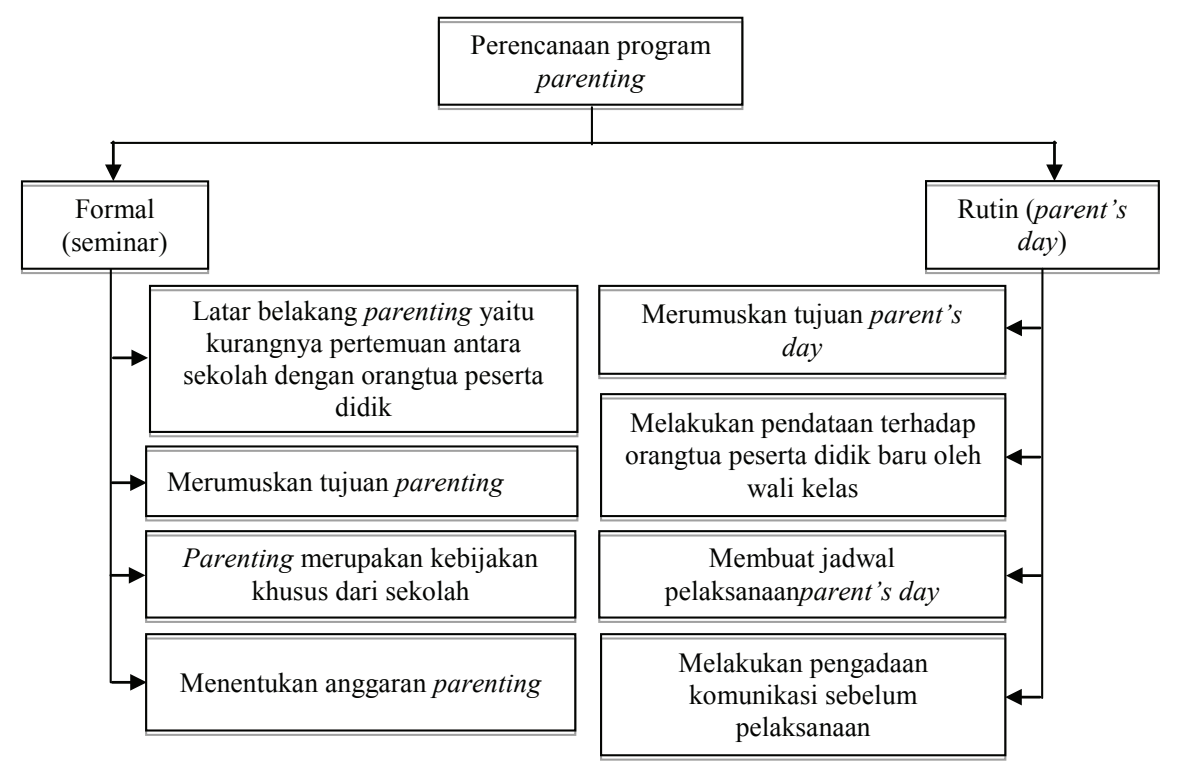

Gambar 1 Perencanaan Parenting di SDI Surya Buana Malang 
yaitu seperti program yang akan dilaksanakan bukanlah berasal dari pemerintah tetapi berasal dari ide sekolah itu sendiri, dan terakhir yaitu menentukan anggaran yang akan digunakan dalam pelaksanaan.

Sedangkan perencanaan parenting parent's day yaitu pertama dengan menentukan dan merumuskan tujuan dari adanya program ini, kemudian wali kelas melakukan pendataan terhadap orangtua peserta didik. Perencanaan selanjutnya yaitu wali kelas membuat jadwal pelaksanaan program. Adapun pembuatan jadwal disesuaikan dengan absensi peserta didik mulai dari absensi awal hingga absensi terakhir. Selain itu, pembuatan jadwal juga disesuaikan dengan kelender pendidikan. Perencanaan terakhir yaitu wali kelas diharuskan menghubungi orangtua peserta didik sebelum pelaksanaan berlangsung. Adapun bagan temuan penelitian dari perencanaan parenting di SDI Surya Buana Malang diilustrasikan pada Gambar 1.

\section{Pengorganisasian Tugas dan Tanggung Jawab Parenting}

Pengorganisasian parenting seminar yaitu terdiri dari kepanitiaan yang melibatkan seluruh yayasan mulai dari jenjang TK, SD, MTs, dan SMA. Adapun kepanitiaan yang dipilih dari jenjang SD adalah Kepala Sekolah, Wakil Kepala Sekolah Kesiswaan, Wakil Kepala Sekolah Humas, Wakil Kepala Sekolah Kurikulum, dan Wakil Kepala Sekolah Sarpras. Namun dalam hal ini kepanitiaan dari Waka Kesiswaan yang sering dilibatkan dalam kepanitiaan karena Waka ini merupakan tempat bersandar atau tempat yang menangani segala persoalan peserta didik. Pengorganisasian selanjutnya yaitu mengenai kegiatan rapat kooordinasi antar panitia yang mana membahas mengenai tugas masing-masing anggota.

Sedangkan pengorganisasian parenting parent's day yaitu kepanitiaan yang langsung dari wali kelas masing-masing, sehingga segala macam kegiatan mengenai program ini ditangani langsung oleh wali kelas. Namun demikian, penanggungjawab terhadap adanya program ini sepenuhnya tetap berada pada Kepala Sekolah selaku pimpinan sekolah. Adapun bagan temuan penelitian dari pengorganisasian tugas dan tanggung jawab parenting di SDI Surya Buana Malang sebagaimana diilustrasikan Gambar 2.

\section{Pelaksanaan Parenting}

Pelaksanaan Parenting seminar di Surya buana Malang merupakan kerjasama sekolah dengan orangtua peserta didik yang mana waktu pelaksanaan program ini dilaksanakan setiap satu tahun sekali bahkan bisa lebih dari satu kali dengan melibatkan seluruh yayasan yaitu orangtua peserta didik mulai dari jenjeng TK, SD, MTs, dan SMA. Selain itu, keterlibatan lainnya yaitu berasal dari tamu undangan yang sengaja diundang oleh pihak yayasan. Adapun pemateri yang mengisi acara tersebut berasal dari luar Kota yaitu Jakarta dan Surabaya yang ahli dalam memberikan materi mengenai parenting sehingga dapat memberikan manfaat tersendiri bagi sekolah, orangtua peserta didik, dan peserta didik.

Sedangkan pelaksanaan parenting parent's

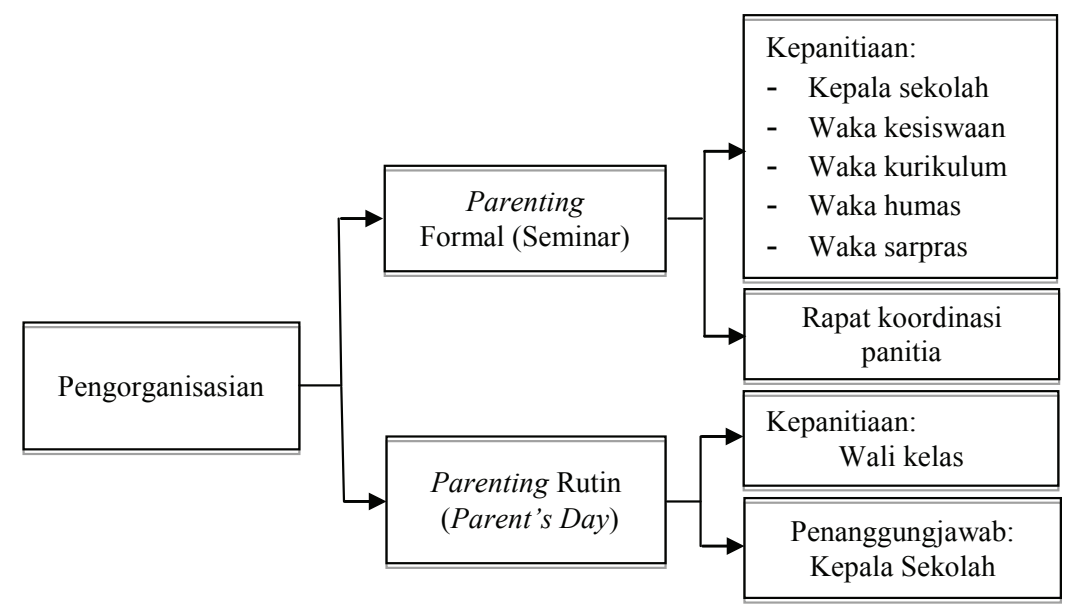

Gambar 2 Pengorganisasian Tugas dan Tanggung Jawab Parenting 
day dilaksanakan setiap minggu sekali tepatnya hari Sabtu dengan waktu sekitar 35 menit untuk satu kali pelaksanaan, adapun waktu 30 menit merupakan waktu yang diberikan untuk orangtua peserta didik yang belum sempat menyampaikan materinya. Sasaran program ini adalah peserta didik Kelas I, II, dan III, sehingga terdapat halhal yang perlu diperhatikan oleh orangtua peserta didik sebelum terlaksananya kegiatan yaitu seperti persiapan terhadap bahan materi yang akan disampaikan dan mental orangtua peserta didik itu sendiri. Materi yang disampaikan dalam pelaksanaan bertemakan bebas sehingga disesuiakan berdasarkan kemampuan masingmasing orangtua peserta didik, dan untuk materi yang sering disampaikan oleh orangtua peserta didik adalah bertemakan keterampilan. Adanya kegiatan ini mendapat respon yang baik dari peserta didik sendiri. Bagan temuan penelitian dari pelaksanaan parenting di SDI Surya Buana Malang diilustrasikan Gambar 3.

\section{Evaluasi Parenting}

Keterlibatan evaluasi parenting seminar yaitu dari pihak panitia. Sedangkan Parenting parent's day dari wali kelas bersama beberapa orangtua. adapun materi yang dibahas kedua parenting adalah mengenai faktor pendukung, penghambat, dan strategi meminimalisasi hambatan. Hasil dari evaluasi parenting seminar yaitu pelaksanaan sudah berjalan dengan baik dan telah mencapai target dari sekolah itu sendiri, adapun evaluasi dilaksanakan melalui rapat panitia. Sedangkan hasil dari parenting parent's day yaitu pelaksanaan dirasa masih kurang maksimal karena masih banyaknya orangtua yang tidak hadir dalam pelaksanaan, adapun evaluasi tersebut dilakkukan dengan cara sharing antara wli kelas dengan orangtua peserta didik. bagan temuan penelitian

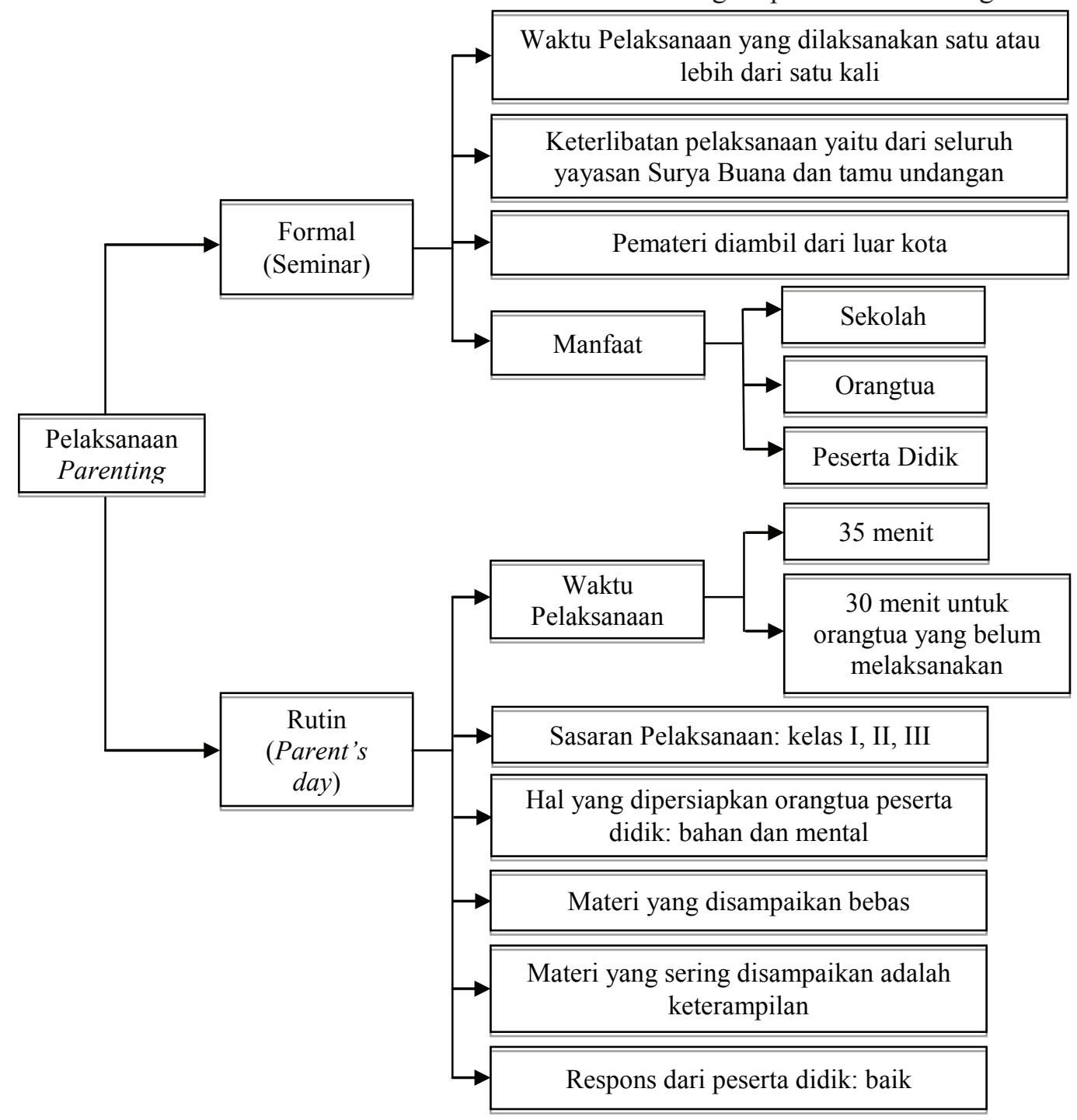

Gambar 3 Pelaksanaan Parenting 


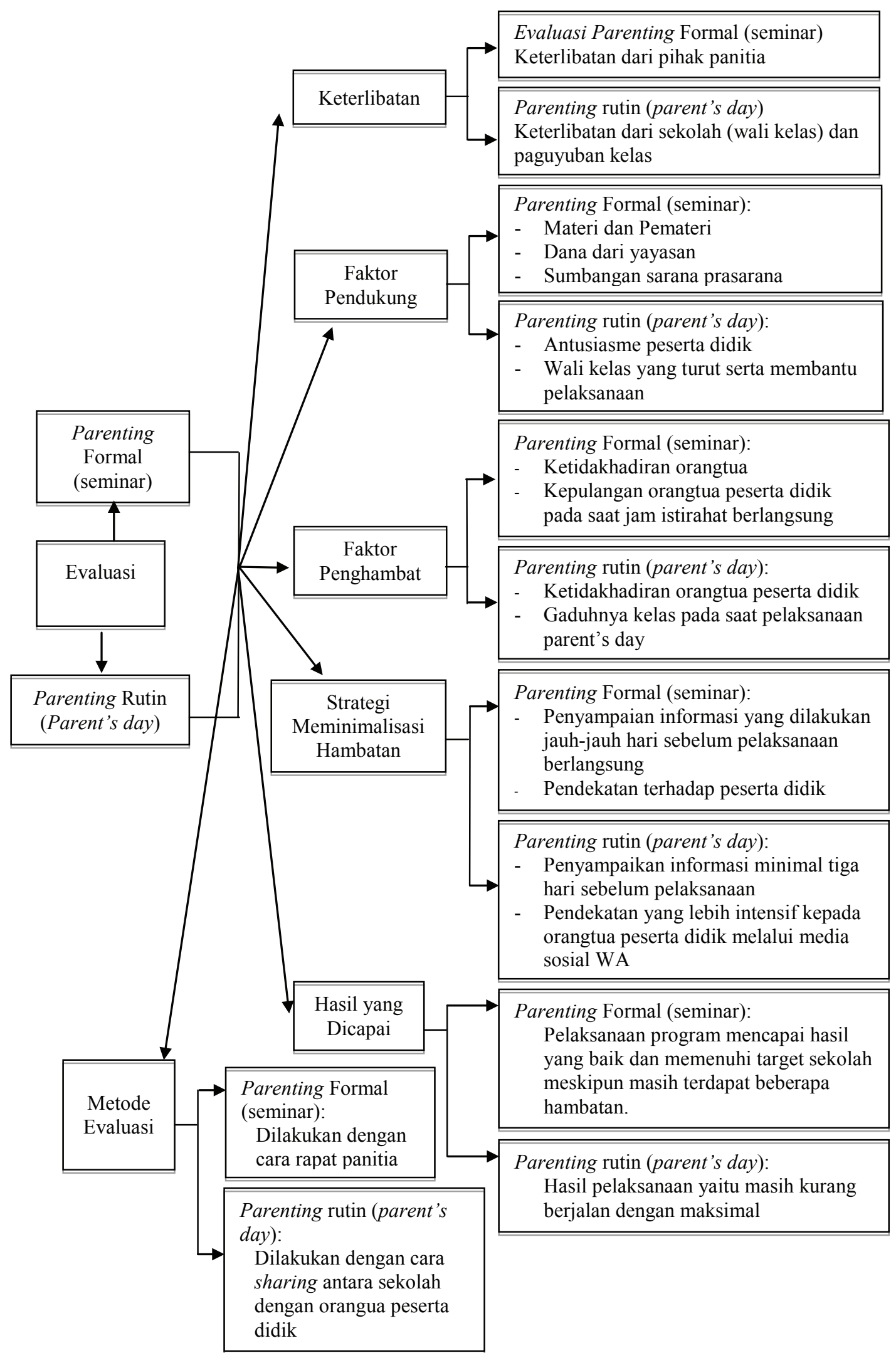

Gambar 4 Evaluasi Parenting di SDI Surya Buana Malang 
dari evaluasi parenting di SDI Surya Buana Malang sebagaimana terlihat pada Gambar 4.

\section{PEMBAHASAN}

Berdasarkan hasil penelitian diketahui bahwa terdapat dua bentuk parenting ada di sekolah. Kedua bentuk parenting yang dimaksud adalah parenting formal atau seminar dan parenting rutin yang disebut dengan parent's day. Kedua parenting dibuat pada akhir tahun pembelajaran atau setiap akhir semester yang mana parenting merupakan program jangka pendek yaitu kurang dari lima tahun. Perencanaan pendidikan tersebut salah satunya terdapat jenis parenting dalam jangka pendek (Fattah, 2006), seperti di SDI Surya Buana Malang yang dilaksanakan setiap semester dan tahunan sebagai programnya.

Program yang dilakukan sekolah sesuai dengan yang dipaparkan oleh Harahap (2012) yang memberikan pernyataan mengenai salah satu bentuk program parenting adalah seminar yang dilakukan dengan mengundang narasumber dan sponsor. Kegiatan seminar di sekolah melibatkan seluruh yayasan mulai dari jenjang pendidikan dasar dan menengah. Langkah perencanaan yang dapat dijadikan acuan sebelum pelaksanaan dimulai yaitu dengan menentukan dan merumuskan suatu tujuan yang hendak ingin dicapai (Prihatin, 2011), adapun tujuan dari parenting di SDI Surya Buana Malang sendiri adalah sebagai sarana untuk meningkatkan hubungan sekolah dengan orangtua dan untuk memotivasi para wali murid dalam menangani setiap permasalahan yang terjadi pada anak.

Bentuk parenting yang kedua adalah parent's day yang mana bentuk kegiatan tersebut seperti yang dijelaskan pada pedoman teknik penyelenggaraan pendidikan keorangtuaan (parenting) yang dikeluarkan oleh Direktorat Pendidikan Nonformal dan Informal (2010) yaitu hari orangtua (parent's day) yang mana kegiatan ini dilakukan dengan melibatkan orangtua atau keluarga dalam proses pembelajaran. Pernyataan tersebut sesuai dengan yang dilaksanakan di SDI Surya Buana Malang yang mana parents day melibatkan orangtua dalam pembelajaran. Perencanaan yang dimaksud dengan langkah-langkah dimulai dengan adanya tujuan kegiatan yang dilaksanakan (Prihatin, 2011).

Mulyono (2010) menyatakan beberapa prinsip yang perlu untuk diperhatikan dalam pelaksanaan hubungan sekolah dengan masyarakat adalah: (1) keterpaduan (integrity); (2) berkesinambungan (continuity); (3) sederhana (simplicity); (4) menyeluruh (converage); (5) konstruktif (constuctiveness); (6) kesesuaian (adaptability); dan (7) luwes (flexibility). Bentuk partisipasi masyarakat adalah: (1) partisipasi buah pikiran/ide, sumbangan pikiran, pengalaman dan pengetahuan yang diberikan dalam pertemuan, diskusi sehingga menghasilkan suatu keputusan; (2) partisipasi tenaga, dengan memberikan tenaga dan waktu untuk menghasilkan sesuatu yang telah diputuskan; (3) partisipasi keahlian atau keterampilan, di mana seseorang bertindak sebagai ahli, penasihat, atau resources yang diperlukan dalam kegiatan pendidikan di sekolah; dan (4) partisipasi harta benda, berupa iuran atau sumbangan, baik dalam bentuk benda atau uang secara tetap atau incidental (Prihatin, 2011).

Tujuan parent's day di SDI Surya Buana Malang senada dengan tujuan parenting seminar yaitu sebagai sarana untuk meningkatkan hubungan sekolah dengan orangtua dan untuk memotivasi para wali murid dalam menangani setiap permasalahan yang terjadi pada anak. Manfaat parenting adalah: (1) terjalinnya mitra kerja lintas sektor, misalnya dari pengusaha yang berkaitan dengan produk yang berkaitan dengan kebutuhan tumbuh kembang anak, instansi pemerintah, dan penerbitan buku; (2) terpenuhinya kebutuhan hak-hak anak; (3) berkembangnya rasa 
percaya diri orangtua dalam mendidik anak; (4) terjalinnya hubungan yang harmonis pada masing-masing anggota keluarga dengan tugasnya masing-masing; (5) terciptanya hubungan antara keluarga di lingkungan masyarakat sekitar lembaga pendidikan; dan (6) terjalinnya mitra kerja sesama anggota parenting (Harahap, 2012).

Pengorganisasian parenting di SDI Surya Buana Malang senada dengan pendapat yang dikemukakan oleh Yamin dan Maisah (2009), pengorganisasian merupakan sebuah proses secara keseluruhan setelah adanya perencanaan untuk mengelompokkan, baik orang-orang, alat-alat, tanggung jawab, atau wewenang berdasarkan pada tugas masingmasing orang. Pengorganisasian parenting di sekolah melibatkan masing-masing orang pada setiap jenjang pendidikan yang ditunjuk oleh yayasan, untuk jenjang SD kepanitiaan yang ditunjuk adalah kepala sekolah, wakil kepala sekolah kesiswaan, wakil kepala sekolah kurikulum, wakil kepala sekolah sarpras, dan wakil kepala sekolah humas. Guru yang berkompeten diperlukan dalam kepanitiaan. Pengorganisasian disesuaikan dengan pengalaman, bakat, minat, pengetahuan, dan kepribadian masingmasing orang (Prihatin, 2009).

Berkaitan dengan pengorganisasian parenting yang kedua yaitu parent's day, pengorganisasian hampir sama dengan parenting formal yang mana program tersebut berada dalam naungan yayasan. Hal yang menjadi perbedaan pengorganisasian yaitu terletak pada yayasan yang tidak terlibat secara penuh dalam pelaksanaan meskipun berada dalam naungan tersebut. Kepanitiaan tertinggi parent's day adalah kepala sekolah yang kemudian diserahkan langsung kepada masing-masing wali kelas. Differences in parental attitudes, affective responses, and behaviors toward their children, often generally referred to as parenting (Knafo, dkk., 2011). Parents' reinforcement of prosocial behavior following a request, but not of spontaneous prosocial behavior, related negatively to children's compliant prosocial behavior (Eisenberg, dkk., 1992).

Pelaksanaan Parenting di sekolah yang telah dilaksanakan senada dengan prinsip berkesinambungan dalam pelaksanaan hubungan sekolah dengan masyarakat, pernyataan tersebut dipaparkan oleh Mulyono (2010) yang mana prinsip berkesinambungan tersebut dilakukan secara berkelanjutan antara sekolah dengan orangtua. Berkelanjutan yang dimaksud seperti adanya program parenting yang terus dijalankan dari tahun ke tahun. Selain itu, sekolah juga menerapkan prinsip menyeluruh dan luwes dalam program parenting. Pelaksanaan parenting seminar sesuai dengan pendapat Harahap (2012) yang dilaksanakan dengan mengundang narasumber dari luar sekolah. Adapun narasumber yang sering memberikan materi di sekolah berasal dari luar kota yakni Surabaya dan Jakarta. Adapun materinya berasal dari permasalahan yang sedang terjadi pada peserta didik. Dengan demikian, pelaksanaan dapat bermanfaat baik itu bagi sekolah, orangtua, dan peserta didik.

Pelaksanaan parentingparent's day merupakan kegiatan rutin yang dilaksanakan setiap hari Sabtu dengan melibatkan orangtua peserta didik sebagai pebelajarnya sehingga sesuai pada teori pedoman teknis penyelenggaraan pendidikan keorangtuaan (parenting) yang dikeluarkan oleh Direktorat Pendidikan Nonformal dan Informal (2010) bahwa dalam hari orangtua (parent's day) melibatkan orangtua atau keluarga dalam proses pembelajaran seperti keterlibatan orangtua di dalam kelas yang dilakukan secara bergiliran berdasarkan jadwal yang diatur pendidik. Sasaran pelaksanaan yaitu Kelas I, II, dan III.

Evaluasi parenting seminar diadakan sebanyak dua kali dalam setahun sehingga menghasilkan evaluasi yang tidak sama. Evaluasi itu dilakukan setelah selesainya pelaksanaan parenting dan satu minggu 
setelah kegiatan parenting dengan cara rapat seluruh panitia. Evaluasi yang diterapkan oleh SDI Surya Buana Malang senada dengan adanya ciri-ciri penilaian yang dikemukakan oleh Arikunto (2009), ciri-ciri penilaian di sekolah bersifat relatif sehingga penilaian tidak selalu sama atau tidak selalu tetap dari satu waktu ke waktu yang lain. Adapun hasilnya yaitu seperti pelaksanaan berjalan dengan baik dan sudah memenuhi target sekolah meskipun masih terdapat beberapa hambatan dalam pelaksanaannya. Namun demikian, sekolah selalu memberikan solusi terhadap setiap hambatan yang terjadi untuk pelaksanaan tahun berikutnya.

Evaluasi parent's day dilakukan antara sekolah dan orangtua peserta didik dengan cara sharing bersama. Sekolah yang dimaksud adalah wali kelas, sedangkan orangtua peserta didik adalah beberapa orangtua yang dijadikan kepengurusan dalam paguyuban kelas. Evaluasi ini dilakukan pada pertengahan semester dan akhir semester, namun sering diadakan pada akhir semester. Evaluasi dapat dilakukan pada tahap terakhir setelah tahap-tahap penelitian, perencanaan, dan penggerakan yang dilaksanakan oleh suatu organisasi (Minarti, 2011). Adapun hasil dari evaluasi ini adalah pelaksanaan yang masih kurang maksimal akibat masih banyaknya orangtua peserta didik yang tidak hadir dalam pelaksanaan.

\section{SIMPULAN DAN SARAN}

Simpulan yang diperoleh dari penelitian ialah terdapat dua bentuk program parenting yaitu: (1) parenting formal, kegiatannya seperti seminar; dan (2) parenting rutin, kegiatannya seperti parent's day dengan latar belakang pada kurangnya pertemuan antara sekolah dengan orangtua peserta didik. Adapun perencanaan parenting seminar adalah dengan menentukan dan merumuskan suatu tujuan, menentukan kebijakan khusus dari sekolah, dan menentuan anggaran pelaksanaan. Sedangkan perencanaan parent's day yang ada adalah menentukan tujuan parent's day, melakukan pendataan terhadap orangtua peserta didik. Pengorganisasian parenting seminar di SD, seperti kepala sekolah, wakil kepala sekolah kesiswaan, wakil kepala sekolah kurikulum, wakil kepala sekolah sarpras, dan wakil kepala sekolah humas. Selanjutnya yaitu melakukan rapat koordinasi panitia yang membahas masalah job description masingmasing panitia. Sedangkan pengorganisasian parenting parent's day yaitu diserahkan langsung kepada masing-masing wali kelas sehingga kepala sekolah sebagai panitia yang bertanggungjawab terhadap pelaksanaan.

Pelaksanaan Parenting seminar dilaksanakan setiap satu tahun sekali sekitar bulan September dengan mengundang narasumber dari luar. Adapun materi yang disampaikan berdasarkan pada permasalahan yang sedang terjadi pada saat ini. Parenting yang diadakan oleh yayasan melibatkan seluruh orangtua mulai dari jenjang TK, SD, MTs, SMA yang mana pelaksanaannya dilaksanakan pada pukul 08.00 s.d. 15.00. Sedangkan pelaksanaan parent's day dilaksanakan secara rutin yang mana pelaksanaannya setiap hari Sabtu dengan orangtua peserta didik yang menjadi pebelajarnya. Sasaran pelaksanaan adalah kelas I, II, dan III yang mana materi yang disampaikan mengandung unsur bebas dengan adanya waktu sekitar 35 menit untuk satu kali pelaksanaan.

Adapun materi yang sering disampaikan adalah tentang keterampilan sehingga orangtua perlu mempersiapkan bahan dan mental mereka sebelum menyampaikan materi kepada peserta didik. Adanya program ini memberikan respon yang baik bagi peserta didik. Terakhir yaitu evaluasi parenting di SDI Surya Buana Malang pada program fomal seminar tidak melibatkan orangtua peserta didik melainkan hanya kepanitiaan saja. Adapun hasil evaluasi yaitu berjalan dengan baik dan sesuai dengan target dari sekolah, evaluasi tersebut dilakukan dibagi menjadi dua yaitu setelah selesainya pelaksanaan dan satu minggu setelah pelaksanaan dengan cara rapat yang dilakukan oleh panitia.

Bahasan pada evaluasi adalah mengenai faktor pendukung dan penghambat pelaksanaan 
serta strategi untuk meminimalisasi adanya hambatan yang terjadi. Berkaitan dengan evaluasi parenting seminar, bahasan dalam evaluasi parent's day sama dengan evaluasi seminar yaitu mengenai faktor pendukung dan penghambat pelaksanaan serta strategi meminimalisasi adanya hambatan tersebut. Pelaksanaan evaluasi parent's day melibatkan wali kelas dan orangtua peserta didik. Adapun evaluasi dilakukan dengan cara sharing antara wali kelas dengan orangtua peserta didik, sehingga hasil dari evaluasi tersebut yaitu pelaksanaan masih kurang maksimal dikarenakan masih banyak orangtua peserta didik yang tidak hadir.

Berdasarkan temuan penelitian, dapat diberikan saran kepada: Bagi Kepala Sekolah Dasar Islam (SDI) Surya Buana Malang yaitu diharapkan SDI Surya Buana Malang dapat lebih menyelaraskan waktu pelaksanaan parenting dan waktu orangtua peserta didik supaya orangtua peserta didik dapat hadir dalam pelaksanaan parenting. Selain itu sekolah diharapkan dapat mengimplementasikan bentuk parenting yang lainnya karena masih terdapat bentuk parenting seperti hari konsultasi dan lain sebagainya yang mampu membantu orangtua dalam mendidik anaknya di lingkungan keluarga.

Kepada Guru Sekolah Dasar Islam (SDI) Surya Buana Malang sebaiknya lebih mengintensifkan komunikasi dengan orangtua peserta didik supaya orangtua peserta didik dapat mengikuti segala program yang dijalankan oleh sekolah. Bagi Orangtua Peserta Didik Sekolah Dasar Islam (SDI) Surya Buana Malang sebaiknya orangtua peserta didik diharapkan dapat lebih mementingkan perkembangan anaknya terutama terhadap pembentukan kepribadian anak. Oleh sebab itu orangtua sebaiknya mengikuti segala program yang dilaksanakan oleh pihak sekolah terutama yang berkaitan dengan anak mereka.

Bagi Kepala Dinas Pendidikan dan Kebudayaan diharapkan aktif dalam memberikan pelatihan mengenai konsep manajemen program parenting kepada pihak-pihak yang berperan secara langsung dalam penyelenggaraan parenting di sekolah. Bagi Peneliti Lain sebaiknya berdasarkan nilai pentingnya hubungan sekolah dengan orangtua, disarankan kepada peneliti yang akan datang untuk menyempurnakan teori hasil penelitian yang telah ditemukan, sehingga diharapkan dapat menambah dan mengembangkan kajian teori yang dapat dijadikan masukan baru bagi kelanjutan penelitian di masa yang akan datang.

\section{DAFTAR RUJUKAN}

Arikunto, S. 2012. Dasar-dasar Evaluasi Pendidikan. Jakarta: Bumi Aksara.

Chang, M. P. B., dan Sunha, K. 2009. Parental Involvement and Parenting Classes. The School Community Journal, 19(1). (Online), (http://files. eric.ed.gov/fulltext/EJ847434.pdf), diakses 01 April 2016.

Dirjen Pendidikan Non Formal dan Informal. 2010. Pedoman Teknis Penyelenggaraan Pendidikan Keorangtuaan (Parenting). Jakarta: Departemen Pendidikan Nasional.

Eisenberg, N., Wolchik, S. A., Goldberg, L., dan Engel, I. 1992. Parental Values, Reinforcement, and Young Children's Prosocial Behavior: A Longitudinal Study. Journal of Genetic Psychology, 153:19-36.

Eisenberg, N., Zhou, Q., Spinrad, T. L., Valiente, C., Fabes, R. A., dan Liew, J. C. 2005. Relations among Positive Parenting, Children's Effortful Control, and Externalizing Problems: A ThreeWave Longitudinal Study. Child Development, 76 : 1055-1071.

Fattah, N. 2006. Landasan Manajemen Pendidikan. Bandung: PT Remaja Rosdakarya.

Harahap, M. 2012. Program Parenting pada Kelompok Bermain. (Online), (http://ipisumedang. blogspot.co.id/2012/04/program-parenting-padakelompok-bermain.html), diakses 11 Februari 2016.

Hasbullah. 2005. Dasar-dasar Ilmu Pendidikan. Jakarta: PT. Raja Grafindo Persada.

Ilahi, M.T. 2013. Quantum Parenting: Kiat Sukses Mengasuh Anak Secara Efektif dan Cerdas. Jogjakarta: Kata Hati.

Knafo, A., Israel, S., dan Ebstein, R. P. 2011. Heritability of Children's Prosocial Behavior and Differential Susceptibility to Parenting by Variation in the Dopamine Receptor D4 Gene. Development and Psychopathology, 23: 53-67.

Minarti, S. 2011. Manajemen Sekolah: Mengelola Lembaga Pendidikan Secara Mandiri. Jogjakarta: Ar-Ruzz Media.

Mulyono. 2010. Manajemen Administrasi dan Organisasi Pendidikan. Jogjakarta: Ar-Ruzz Media.

Prihatin, E. 2011. Teori Administrasi Pendidikan. Bandung: Alfabeta.

Sugiyono. 2013. Metode Penelitian Kuantitatif Kualitatif dan $R \& D$. Bandung: Alfabeta.

Wiyono, B. B. 2007. Metode Penelitian Pendidikan Kuantitatif, Kualitatif, dan Action Research. Malang: Universitas Negeri Malang.

Yamin, M., dan Maisah. 2009. Manajemen Pembelajaran Kelas. Jakarta: Gaung Persada 